\title{
СОЦІАЛЬНО-ПСИХОЛОГІЧНЕ ЗАБЕЗПЕЧЕННЯ ЕКОНОМІЧНОЇ СОЦІАЛАЗАЦІЇ МОЛОДІ У ПРОСТОРІ ОСВІТИ У ВНЗ: МОРАЛЬНИЙ АСПЕКТ
}

УДК: 159.923

\section{Лавренко О.В.}

Кандидат філософських наук, дочент, провідний науковий співробітник лабораторії організачійної та соиіальної психології, Інститут психології імені Г.С. Костюка НАПН Украӥни, м. Київ (Украӥна)

\begin{abstract}
Анотація. У статті розглядається сутність соціально-психологічного забезпечення економічної сочіалізації студентської молоді на засадах моральних цінностей. Воно нами розуміється як сукупність спеціальних психолого-педагогічних форм, методів і засобів їх розгортання в спеціально організованому психолого-педагогічному прочесі. Основою, стратегічною метою, результатом иього забезпечення $\epsilon$ формування підприємливого, економічно грамотного спеціаліста, з економічною культурою, яка передбачає засвоєння ним тих сочіально-економічних норм та цінностей, навичок, економічних ролей, зразків економічної та монетарної поведінки, які трунтуються на моральних иінностях.
\end{abstract}

Ключові слова: особистість, економічна сочіалізачія, забезпечення економічної сочіалізації, моральність, когнітивний, аксіологічний, конативний компоненти.

\section{Постановка проблеми у загальному} вигляді та їі зв'язок із важливими науковими чи практичними завданнями. Соціальноекономічні зміни, розбудова соціальноорієнтованої економіки поставили перед українським суспільством завдання сформувати ринкову економічну культуру молоді, яка б сприяла здійсненню нею ефективної економі- чної діяльності й уможливлювала б оцінювання даної діяльності з позиції не лише економічної доцільності, але й соціальної спрямованості та моральної цінності.

Економічна соціалізація сучасної молоді відбувається в умовах економічної кризи, ознаками якої $є$ : швидке падіння виробництва, закриття підприємств, банкрутство банків, 
ріст безробіття в усіх галузях економіки та по більшості професій, висока інфляція, нерівномірність розвитку регіонів та галузей народного господарства, поглиблення розриву в доходах населення та його швидке розшарування та ін.. Цей процес доповнюється загальною системною суспільно-економічною та духовною кризою суспільства, стрімкою економічною, політичною, соціальною, ідеологічною переорієнтацією, воєнними діями на Сході нашої країни.

Сьогодні стає очевидним, що для формування морального імунітету до негативних проявів в економічній діяльності, економічній культурі особистості як культури ринкових взаємовідносин недостатньою домінуючої теоретичної та вузькоспеціалізованої професійної підготовки молоді. Підвищення економічної культури молоді потребує ефективного комплексного підходу. За умов ринкових відносин від закладів освіти вимагається швидке реагування, тому основною вимогою до випускників є здатність швидко адаптуватися до нових ринкових реалій.

Метою статті $\epsilon$ теоретичний аналіз соціально-психологічного забезпечення економічної соціалізації молоді в просторі вузівської освіти (моральний аспект).

Виклад основного матеріалу і результатів дослідження. Теоретико-методологічну основу дослідження «Соціально-психологічне забезпечення економічної соціалізації молоді в просторі вузівської освіти: моральний ас- пект» складають

ряд теоретикометодологічних підходів, фундаментальних та прикладних психологічних розробок щодо економічної соціалізації молоді. Це, зокрема, розробка психологічних детермінант економічної соціалізації особистості (А.Журавльов, А.Купрейченко, В.Позняков, Л.Хитрош, та ін.); вікових особливостей та відмінностей різних стадій соціалізації (Г.Аверьянова, З.Антонова, О.Козлова, П.Уеблі та ін..); дослідження соціальнопсихологічної сутності та особливостей економічної соціалізації сучасної молоді, становлення iï економічної суб'єктності, закономірностей розвитку економічної культури молоді, здійснене співробітниками лабораторії соціальної психології Інституту психології імені Г.С.Костюка НАПН України (Н. Дембицька, Т. Говорун, І. Зубіашвілі, О. Лавренко, Л. Карамушка, В. Москаленко). Також теоретико-методологічними засадами є дослідження загальних тенденцій засвоєння моральних норм, перехід зовнішнього морально-етичного припису в особисту норму (Л. Божович, О. Кульчицька, В. Мухіна, Є. Субботський, С. Якобсон, А. Бандура, I. Бех, М. Боришевський, І. Булах, 3. Карпенко, Л. Кольберг, С. Максименко, В. Москалець, Ж. Піаже, С. Рубінштейн, Н. Чепелєва, С. Якобсон та ін.); грунтовне комплексне теоретичне та емпіричне дослідження морально-психологічної регуляції економічної активності представників різних соціальних груп сучасної Росії пси- 
хологів РАН під керівництвом А. Л. Журавльова та А. Б. Купрейченко. Взаємозв 'язок економічного та морального виховання у школярів та студентської молоді вивчався також російськими науковцями (Н.M. Тарарухіна, Л. Г. Борисова, Г. С. Солодова, О. П. Фадеева, I. І. Харченко, Р.М. Шайдулліна та ін..). Особлива роль моральних феноменів в детермінації економічної поведінки визначає високий інтерес дослідників до морального аспекту вивчення економічної свідомості. Здійснені емпіричні дослідження таких феноменів як моральна оцінка грошей, ставлення до дотримання моральних норм, довіра/ недовіра у діловій взаємодії, ставлення до неетичної реклами та ін. дозволяють зробити висновок про наявність специфічних закономірностей їх формування, взаємозв язків між ними та їх впливу на економічну поведінку суб `єкта (Е. Горбачова, А. Купрейченко, 2006; А. Журавльов, А. Купрейченко, 2003, 2007; А. Купрейченко, 2010). Однак проблема моральних аспектів соціально-психологічного забезпечення економічної соціалізації молоді в просторі вузівської освіти потребує подальшого наукового дослідження.

Освіта загалом та вища освіта, зокрема, відіграють унікальну роль в суспільстві, вони відтворюють особистість, озброюють іiі сучасними знаннями, формують світогляд і творчі здібності, виховують як громадянина та патріота. Система вищої освіти тісно пов язана 3 юнацтвом. Вуз є одним із важливіших інсти- тутів соціалізації молодої людини.

Як відомо, соціалізація - це процес формування соціальних якостей особистості, завдяки яким вона активно адаптується в суспільстві, стає суб єктом життєдіяльності. Так чи інакше людина своєю діяльністю «входить» у всі сфери суспільства, зокрема й у економічну. Остання потребує розвинених економікопсихологічних властивостей, формування яких здійснюється в процесі економічної соціалізації, завдяки чому індивід стає суб єктом економічної діяльності. Економічну соціалізацію особистості можна розглядати як трикомпонентний процес (когнітивний, аксіологічний та конативний компоненти). В процесі економічної соціалізації особистість отримує можливість діяти в економічному просторі. Завдяки когнітивній складовій економічної соціалізації індивід засвоює економічні знання, базові економічні поняття та категорії, оволодіває основами знань про сучасну економіку, принципи та закономірності їі функціонування.

Аксіологічний компонент економічної соціалізації забезпечує формування ставлення особистості до системи цінностей та моральних норм, наповнює етичним змістом економічну діяльність людини. Вона активно засвоює економічні цінності (праця, власність, гроші та ін.), різні соціальні ролі (виробник, споживач, платник податків, власник, підприємець, акціонер тощо). Ідеал «економічної людини» $з$ іï особливими ціннісними настанов- 
леннями може обслуговувати як руйнівні, так і творчі дії суб`єкта ринкової економіки. Етичний смисл мотивації «особистісного успіху», мотивів накопичення грошей, багатства активно впливають на формування та акценти особистісних пріоритетів в індивідуальній системі цінностей молодої людини. Сучасна молодь живе в «епоху грошей», коли споживча модель ринкової економіки формує у неї настановлення, що гроші - основна цінність у житті. Товарно-грошові відносини все глибше проникають в систему освіти, формуючи особливий стиль ставлення студентів до навчання, коли знання, оцінки, диплом мають грошовий еквівалент [ [5, с. 238 ].

При включенні в реальні економічні процеси у молодих людей здійснюється оцінка себе на ринку праці, йде пошук шляхів досягнення економічної незалежності, формується уявлення про власний бюджет, особливості ощадної та споживчої поведінки, відбувається професійна орієнтація чи вибір кар`єри, починається знайомство 3 банківською системою, відбувається подальше формування ціннісно-моральних орієнтацій. Конативний компонент процесу економічної соціалізації полягає в тому, що у особистості формується власна стратегія усвідомленої економічної поведінки, що дозволяє реалізувати свої економічні інтереси, задовольнити свої потреби з орієнтацією на соціальні настановлення та мораль, вироблені в суспільстві.

На процес економічної соціалізації моло- ді впливають різні фактори, які можна в цілому поділити на стихійні (формуються під впливом соціального середовища завдяки здатності особистості здійснювати вибір) та організовані (економічна освіта та економічне виховання). Звичайно, поєднання детермінант соціалізації є унікальним для кожної особистості. Особливість становища молодих людей у суспільстві полягає в тому, що, з одного боку, вони входять у той соціальний простір, який було організовано незалежно від них попередніми поколіннями; 3 іншого боку, молодь може змінити та перебудувати відповідні соціальні структури. Крім того, вихід із кризової ситуації і процес розвитку нашого суспільства безпосередньо пов'язані зі становищем молоді та іiі реальною участю в цьому процесі. Тому дослідження процесу включення молодого покоління у всі сфери суспільного життя, зокрема, економічного, набуває особливого значення.

Економічна соціалізація студентської молоді має свої особливості, оскільки на цьому життєвому етапі до тих проблем, 3 якими зіштовхується молода людина при переході до дорослого життя додається ще необхідність вирішення задач економічного та професійного самовизначення. У студентські роки відбувається швидкий перехід від повної економічної залежності від сім ї до певної економічної самостійності. Причиною раннього знайомства молоді з економічною сферою є зниження державної фінансової підтримки студентів. 
Тому частина молодих людей, щоб забезпечити собі гідний рівень існування, рано починає професійну кар`єру, автоматично стаючи економічним суб ‘ктом.

Забезпечення економічної соціалізації особистості студента має на меті, враховуючи стихійний характер становлення економікопсихологічних якостей студентської молоді, сприяти розвиткові іï властивостей і тих соціально-психологічних якостей, які відповідають певному типові економічної культури, що превалює в суспільстві. У своєму матеріальному і духовному виявленні простір економічної культури - це система ціннісних орієнтирів та моральних норм, згідно з якими організовані будь-які зв'язки між людьми в суспільстві, це ціннісно-моральна матриця, яка конституює, зцементовує ці зв'язки в єдине ціле. Економічні цінності суспільства, інтеріоризуючись особистістю в процесі соціалізації і стаючи системою іiї економічних ціннісних орієнтацій, безпосередньо впливають на економічну соціалізацію студентства.

Різні системи цінностей детермінують різні соціально-психологічні характеристики особистості, які в узагальненому вигляді (в системі ціннісних репрезентацій, ставлень, настановлень тощо) втілюються в певному соціально-історичному типі особистості, який $\epsilon$ відображенням умов життя. Зокрема, система ставлень особистості до таких економічних об'єктів, як власність, гроші, багатство, майно тощо, в яку включається індивід, ре- презентується у свідомості студентської молоді у відповідності з їі віковими індивідуально-психологічними особливостями. В результаті утворюються різні матриці інтерсуб'єктного соціалізуючого психолого-економічного простору, що детермінує економікопсихологічні параметри особистості, зокрема iii економічну культуру.

Зважаючи на це, вузівська системи освіти постає одним з провідних інституціалізованих просторів впливу суспільних цінностей та моральних норм на становлення особистості як суб'єкта економіки. ВНЗ поряд із сім'єю, іншими чинниками соціалізуючого впливу (інтернет, соціальні мережі, 3MI, позааудиторні форми виховного впливу тощо) $є$ важливими регулятивно-символічними просторами формування економічної культури особистості в системі «людина - економічна сфера суспільства».

Соціально-психологічне забезпечення економічної соціалізації студентської молоді у вимірі моральних цінностей ми розуміємо як сукупність спеціальних психологопедагогічних форм, методів і засобів їх розгортання в спеціально організованому психолого-педагогічному процесі, основою, стратегічною метою, результатом якого $\epsilon$ формування підприємливого, економічно грамотного спеціаліста, з економічною культурою, яка передбачає засвоєння студентами тих соціально -економічних норм та цінностей, навичок, економічних ролей, зразків економічної та 
монетарної поведінки, які грунтуються на моральних цінностях. Моральність особистості виступає важливою детермінантою її економічної активності. Відносини моральності суб `єкта значною мірою визначають вибір виду економічної активності, методів і засобів досягнення цілей, а також специфіку його стосунків із партнерами по взаємодії. Теоретична модель моральних аспектів соціальнопсихологічного забезпечення економічної соціалізації студентської молоді включає дослідження психологічного ставлення особистості до дотримання моральних норм, до використання цих норм у повсякденному житті.

Завдяки соціально-психологічному забезпеченню економічної соціалізації у ході навчання у вузі студент повинен сформувати переконання, що в умовах економічної свободи і конкурентних відносин значення етичного регулювання підвищується. Економічна культура весь час наповнюється новими знаннями, які відповідають новому етапу у розвитку економічної системи. I вона тільки тоді виконує свої функції, коли сповнена моральних орієнтирів. Студент повинен чітко засвоїти, що ринкове господарство за своєю суттю не може бути аморальним. Адже воно являє собою такий механізм виробництва і розподілу, який забезпечує отримання матеріальних благ для суспільства в цілому, а не для хижацького збагачення і розкошів окремого індивіда. Діючи в рамках ринкової економіки, люди прагнуть до власної вигоди, але досягти поєднання особистих та суспільних інтересів вони можуть лише тоді, коли спираються на загальновизнаний етичний фундамент.

Студенти повинні розуміти, що як морально допустимі та недопустимі сприймаються різні цілі, види і способи виробництва, розподілу, обміну та споживання, а також рівні доходу та добробуту. Адже в категоріях добра і зла оцінюються різні економічні об єкти та явища (гроші і власність, бідність та багатство, діловий світ та кризи, безробіття та реклама та ін.). Моральними чи аморальними вважаються ті чи інші види відносин між людьми в економічній сфері (партнерство, конкуренція, конфлікти, боргові зобов язання та ін.). На цій основі суб`єкти економічної активності визначають прийнятні чи неприйнятні види економічної діяльності, а також стратегії поведінки в різних умовах та ситуаціях. В той же час обрані чи сформовані умови економічної діяльності здійснюють зворотний вплив на економічне самовизначення ділової людини [3, c. 13-28].

У пору юнацтва відбувається формування моральних ідеалів, але вже не на рівні кумирів, як було на попередньому віковому етапі, а після складної внутрішньої роботи по його пошуку (узагальнений ідеал). Тепер принципи поведінки із нестійких, повністю наслідуваних стають внутрішніми, стійкими, морально наповненими. Відбувається укорінення моральної культури особистості. Лише після цього становлення особистості можна 
вважати закінченим, тобто людина як психологічне і моральне утворення почне діяти як повноцінна особистість.

Мораль здійснює свою регулятивну функцію 3 допомогою спільних для даного суспільства фундаментальних уявлень про добро і зло, правильне і неправильне, гідне і негідне, справедливе і несправедливе. Моральне регулювання передбачає: а) наявність ідеалу, який виражає уявлення суспільства про моральну досконалість і на цій основі містить портрет «кращого Я» особистості; б) систему норм, виконання яких є засобом досягнення моральної цілі (ідеалу); в) оцінку поведінки особистості; г) специфічні форми контролю, які забезпечують виконання норм. Мораль діє там і тоді, де і коли особистість проявляє вільний вибір поведінки, а, отже, несе особисту відповідальність за цей вибір [1, с. 26].

Становлення економічної культури студентів в умовах вузу є процесом, що підлягає управлінню і повинно відповідним чином забезпечуватися. Його успішність залежить як від вивчення теоретичних основ економіки, так і від використання економічних закономірностей при викладанні усіх спеціальних дисциплін.

Економічна соціалізація студентської молоді має свої особливості, так як на цьому етапі життя здійснюється оцінка себе на ринку праці, формується уявлення про власний бюджет, починається знайомство з банківською системою, трудовим відносинами тощо. А.
Вяткін до цих особливостей соціалізації додає ще й ті проблеми, з якими стикається молода людина при переході до дорослого самостійного життя, а саме: пошук шляхів досягнення економічної незалежності, особливості заощадливої та споживчої поведінки, професійна орієнтація чи вибір кар`єри, формування ціннісних орієнтацій в економічній сфері, зміни у самосвідомості [2].

Особистість, що володіє економічної культурою та економічним мисленням, які грунтуються на етичних засадах, повинна: а) вміти адекватно оцінювати процеси, що відбуваються в економічному житті та орієнтуватися в ньому; б) вміти оцінювати державну політику; в) вміти обгрунтовувати технічні рішення $з$ точки зору їх економічної ефективності та морального аспекту; г) вміти грамотно організовувати свою справу та свій побут; д) не спокушатися на сумнівні оборудки, на принади конс'юмеризму.

Економічна культура особистості, яка формується в процесі економічної соціалізації, - це психолого-економічні якості особистості, які є носіями нормативної моделі економічного типу людини, і ці якості зумовлюють входження іiі в «світ економіки». Тому економічна культура особистості - це не просто економічні знання, економіко-фінансова грамотність та інші навички, а, перш за все, особистісні якості, завдяки яким людина здатна діяти в економічному просторі на засадах моральності. Цих здатностей людина набуває в 
процесі економічної соціалізації [4, с. 56].

На наш погляд, комплексна програма соціально-психологічного забезпечення економічної соціалізації студентської молоді на засадах моралі повинна включати такі розділи: «Пізнання» (освітньо-інформаційні заняття, електронна трибуна, лекції-візуалізації, інформ-інтернет-клуби тощо); «Соціальнопрофесійне спілкування» (соціальні дискусії, творчі зустрічі-діалоги, науково-дослідні спільноти тощо); «Соціальна практика» (ініціативні групи, соціальні проекти, акції, волонтерство тощо). 3 метою оптимізації соціально-психологічного забезпечення економічної соціалізації студентів потрібно розробити, апробувати та перевірити ефективність програми ділових ігор (творчі, рольові ігри на економіко-моральну тематику, практикуми тощо). Така комплексна програма забезпечить цілісність набуття студентами соціального досвіду як синтезу соціальних умінь, навичок, знань, способів діяльності, соціально орієнтованого мислення.

Висновки та перспективи подальших досліджень. Узагальнюючи, можна зазначити, що соціально-психологічне забезпечення економічної соціалізації студентської молоді у вимірі моральних цінностей - це сукупність спеціальних психолого-педагогічних форм, методів і засобів їх розгортання в спеціально організованому психологопедагогічному процесі. Основою, стратегічною метою, результатом цього процесу є фор- мування підприємливого, економічно грамотного спеціаліста, з економічною культурою, яка передбачає засвоєння студентами тих соціально-економічних норм та цінностей, навичок, економічних ролей, зразків економічної та монетарної поведінки, які грунтуються на моральних цінностях. Моральність особистості виступає важливою детермінантою іiї економічної активності. Відносини моральності суб єкта значною мірою визначають вибір виду економічної активності, методів і засобів досягнення цілей, а також специфіку його стосунків із партнерами по взаємодії.

В перспективі подалыших досліджень передбачається здійснити емпіричну перевірку теоретичної моделі моральних аспектів соціально-психологічного забезпечення економічної соціалізації студентської молоді.

Перелік використаних джерел:

1. Вичев В. Мораль и социальная психика / Пер. с болг. под общ. ред. Ю.А. Шерковина.- М. «Прогресс». 1978. - 357 c.

2. Вяткин А. П. Психология экономической социализации личности: субъектно-ролевый подход: монография. - Иркутск: Изд-во Иркут. гос. ун-та, 2010. -383 с.

3. Журавлев А. Л., Купрейченко А.Б, Горбачева Е.И. Нравственно-психологические компоненты экономического самоопределения предпринимателей и менеджеров в организации творческого труда / Психология в экономике и управлении. - 2011.- № 1 - С. 13 -28.

4. Соціально-психологічні закономірності становлення економічної культури молоді: монографія / В.В.Москаленко, О.В.Лавренко, Н.М.Дембицька, І.К.Зубіашвілі та ін.; за ред.. В.В.Москаленко - К., 2015 
$-399 \mathrm{c}$.

5. Шайдуллина Р.М. Сущност ь экономической социализации студенческой молодежи в современных условиях / Вестник Челябинского государственного университета. - 2012. - № 1, - С. 231- 242.

\section{References (Transliteration):}

1. Vichev Vasil Moral i sotsialnaya psihika / Per. s bolg. pod obsch. red. Yu.A. Sherkovina / Vasil Vichev - M. «Progress». - 1978. - 357 s.

2. Vyatkin A. P. Psihologiya ekonomicheskoy sotsializatsii lichnosti: sub'ektno-rolevyiy podhod: monografiya./A.P. Vyatkin - Irkutsk: Izd-vo Irkut. gos. un-ta, 2010. -383 s.

3. Zhuravlev A.L., Kupreychenko A.B, Gorbacheva E.I. Nravstvenno-psihologicheskie komponentyi ekonomicheskogo samoopredeleniya predprinimateley i menedzherov $\mathrm{V}$ organizatsii tvorcheskogo truda / A.L. Zhuravlev, A.B Kupreychenko, E.I. Gorbacheva // Psihologiya v ekonomike i upravlenii. - 2011.- \# 1 - S. 13 28.

4. SotsIalno-psihologIchnI zakonomIrnostI stanovlennya ekonomIchnoYi kulturi molodI: monografIya / V.V.Moskalenko, O.V.Lavrenko, N.M.Dembitska, I.K.ZubIashvIlI ta In.; za red.. V.V.Moskalenko - K., $2015-399$ s.

5. Shaydullina R.M. Suschnost ekonomicheskoy sotsializatsii studencheskoy molodezhi v sovremennyih usloviyah / R.M. Shaydullina // Vestnik Chelyabinskogo gosudarstvennogo universiteta. - 2012. - \# 1, - S. 231- 242].

\section{Lavrenko Olga}

PhD, Assoc. Prof., leading researcher, Laboratory of organizational and social psychology, G. S. Kostiuk Institute of Psychology of the National academy of Pedagogical Sciences of Ukraine, Kyiv (Ukraine)

\section{SOCIAL-PSYCHOLOGICAL ENSURING OF ECONOMIC SOCIALIZATION OF YOUTH IN THE AREA OF HIGHER EDU- CATION: THE MORAL ASPECT}

\section{ABSTRACT}

In the article is the essence of socialpsychological ensuring of economic socialization of students on the basis of moral values. We're understood this as a combination of special psychological-pedagogical forms, methods, and means of their deploying in the specially organized psychological-pedagogical process. The basis, strategic goal, the result of this provision is the formation of enterprising, economically literate specialists, with the economic culture which involves the assimilation of his social and economic norms and values, skills, economic roles, patterns of economic and monetary behavior which are based on the moral values.

Economic socialization of the individual can be seen as a three-component process (cognitive, axiological and conative components). Through the cognitive component of economic socialization, an individual assimilates, basic economic concepts and categories, as well as the principles and patterns economy. Axiological economic socialization component contributes to the development of individual attitudes to the system of values and moral standards, fills the ethical content of human economic activity. The conative component promotes the formation of individual conscious strategies of 
economic behavior that allows to realize their economic interests, meet their needs in line with social and moral norms.

Keywords: individual, economic socialization, ensure economic socialization, moral, cognitive, axiological, conative components.

\section{Лавренко Ольга Василевна}

Кандидат философских наук, доиент, ведущий научный сотрудник лаборатории организационной и соииальной психологии, Институт психологии имени Г.С. Костюка АПН Украины, г. Киев (Украина)

\section{СОЦИАЛЬНО-ПСИХОЛОГИЧЕСКОЕ ОБЕСПЕЧЕНИЕ ЭКОНОМИЧЕСКОЙ СОЦИАЛИЗАЦИИ МОЛОДЕЖИ В ПРО- СТРАНСТВЕ ВУЗОВСКОГО ОБРАЗОВА- НИЯ: НРАВСТВЕННЫЙ АСПЕКТ}

\begin{abstract}
Аннотация. В ст ат ье рассмат ривается сущность социально-психологического обеспечения экономической социализации студенческой молодежи, основанной на нравственных ценностях. Нами она представлена как совокупность специальных психологопедагогических форм, методов и средств их применения в специально организованном психолого-педагогическом процессе. Основой, стратегической целью, результатом этого обеспечения есть формирование предприимчивого, экономически грамотного специалиста, с экономической культурой, которая предусматривает усвоение им тех социальноэкономических норм и ценностей, навыков, экономических ролей, образцов экономического и монетарного поведения, которые основаны на нравственных ценностях.
\end{abstract}

Ключевые слова: личност ь, экономическая социализация, обеспечение, нравственность, когнитивный, аксиологический, конативный компоненты. 